\title{
Evaluation of the Long-Term Cost-Effectiveness of Once-Weekly Semaglutide Versus Dulaglutide and Sitagliptin in the Spanish Setting
}

\author{
Virginia Martín · Josep Vidal · Samuel J. P. Malkin · Nino Hallén • \\ Barnaby Hunt (D)
}

Received: June 16, 2020 / Published online: August 29, 2020

(C) The Author(s) 2020

\begin{abstract}
Introduction: Healthcare systems aim to maximize the health of the population, but must work within constrained budgets. Therefore, choosing therapies that are both effective and cost-effective is paramount. The present analysis assessed the cost-effectiveness of onceweekly semaglutide $0.5 \mathrm{mg}$ and $1 \mathrm{mg}$ versus once-weekly dulaglutide $1.5 \mathrm{mg}$ and versus
\end{abstract}

Digital Features To view digital features for this article go to https://doi.org/10.6084/m9.figshare.12745430.

Electronic Supplementary Material The online version of this article (https://doi.org/10.1007/s12325020-01464-1) contains supplementary material, which is available to authorized users.

\section{Martín}

Novo Nordisk Pharma SA, Madrid, Spain

J. Vidal

Endocrinology and Nutrition Department, Hospital

Clínic, Barcelona, Spain

J. Vidal

Centro de Investigación Biomédica en Red en Diabetes y Enfermedades Metabólicas Asociadas (CIBERDEM), Barcelona, Spain

S. J. P. Malkin · B. Hunt $(\square)$

Ossian Health Economics and Communications, Basel, Switzerland

e-mail: hunt@ossianconsulting.com

N. Hallén

Novo Nordisk A/S, Søborg, Denmark once daily sitagliptin $100 \mathrm{mg}$ for the treatment of patients with type 2 diabetes with inadequate glycemic control on oral anti-hyperglycemic medications over patient lifetimes from a healthcare payer perspective in the Spanish setting.

Methods: Cost and clinical outcomes were projected over patient lifetimes using the IQVIA CORE Diabetes Model. Baseline cohort characteristics and treatment effects on initiation of semaglutide $0.5 \mathrm{mg}$ and $1 \mathrm{mg}$, dulaglutide $1.5 \mathrm{mg}$ and sitagliptin $100 \mathrm{mg}$ were based on the once-weekly semaglutide clinical trial program (SUSTAIN 7 and 2). Captured costs included treatment costs and costs of diabetesrelated complications. Projected outcomes were discounted at 3.0\% annually.

Results: Projections of long-term clinical outcomes indicated that once-weekly semaglutide $0.5 \mathrm{mg}$ and $1 \mathrm{mg}$ were associated with improvements in discounted life expectancy of 0.02 and 0.11 years, respectively, and discounted quality-adjusted life expectancy of 0.03 and 0.11 quality-adjusted life years (QALYs), respectively, versus dulaglutide $1.5 \mathrm{mg}$. Compared with sitagliptin, once-weekly semaglutide $0.5 \mathrm{mg}$ and $1 \mathrm{mg}$ were associated with improvements in discounted life expectancy of 0.17 and 0.24 years, respectively and discounted quality-adjusted life expectancy of 0.16 and 0.23 QALYs. The increased duration and quality of life with once-weekly semaglutide $0.5 \mathrm{mg}$ and $1 \mathrm{mg}$ resulted from a reduced cumulative 
incidence and delayed time to onset of diabetesrelated complications. Avoided complications resulted in once-weekly semaglutide $0.5 \mathrm{mg}$ and $1 \mathrm{mg}$ being cost-saving versus dulaglutide $1.5 \mathrm{mg}$ and versus sitagliptin $100 \mathrm{mg}$ from a healthcare payer perspective.

Conclusions: Once-weekly semaglutide $0.5 \mathrm{mg}$ and $1 \mathrm{mg}$ were considered dominant (more effective and less costly) versus sitagliptin $100 \mathrm{mg}$ and dulaglutide $1.5 \mathrm{mg}$ for the treatment of patients with type 2 diabetes with inadequate glycemic control on oral anti-hyperglycemic medications and are likely to be a good use of healthcare resources in the Spanish setting.

\section{PLAIN LANGUAGE SUMMARY}

Since healthcare systems aim to maximize the health of the population but must work within constrained budgets, choosing therapies that are both effective and cost-effective is paramount. We assessed the cost-effectiveness, from a Spanish healthcare payer perspective, of the newly marketed once-weekly semaglutide $0.5 \mathrm{mg}$ and $1 \mathrm{mg}$ versus two established therapies (dulaglutide $1.5 \mathrm{mg}$ and sitagliptin $100 \mathrm{mg}$ ) for the treatment of patients with type 2 diabetes with inadequate glycemic control on oral anti-hyperglycemic medications over patient lifetimes.

Outcomes were projected using a computer simulation model, based on two trials con- ducted as part of the once-weekly semaglutide clinical trial program (SUSTAIN 2 and SUSTAIN 7). Captured costs included treatment costs and costs of diabetes-related complications.

Projections of long-term clinical outcomes indicated that once-weekly semaglutide $0.5 \mathrm{mg}$ and $1 \mathrm{mg}$ were associated with improvements in quality-adjusted life expectancy of 0.03 and 0.11 quality-adjusted life years (QALYs), respectively, versus dulaglutide $1.5 \mathrm{mg}$, and 0.16 and 0.23 QALYs, respectively, versus sitagliptin $100 \mathrm{mg}$. The increased duration and quality of life with once-weekly semaglutide $0.5 \mathrm{mg}$ and $1 \mathrm{mg}$ resulted from a reduced cumulative incidence and delayed time to onset of diabetes-related complications. Avoided complications resulted in once-weekly semaglutide $0.5 \mathrm{mg}$ and $1 \mathrm{mg}$ being cost-saving versus dulaglutide $1.5 \mathrm{mg}$ and versus sitagliptin $100 \mathrm{mg}$.

Once-weekly semaglutide $0.5 \mathrm{mg}$ and $1 \mathrm{mg}$ were more effective and less costly and therefore were considered dominant in both comparisons, and are likely to be a good use of healthcare resources in the Spanish setting.

Keywords: Cost; Cost-effectiveness; Diabetes mellitus; Dulaglutide; GLP-1 receptor agonist; Semaglutide; Sitagliptin; Spain 


\section{Key Summary Points}

Why carry out this study?

Assessment of the cost-effectiveness of new interventions is increasingly important as healthcare systems come under increasing financial pressure.

The present analysis aimed to assess the long-term cost-effectiveness of onceweekly semaglutide $0.5 \mathrm{mg}$ and $1 \mathrm{mg}$ versus dulaglutide $1.5 \mathrm{mg}$ and versus sitagliptin $100 \mathrm{mg}$ for the treatment of patients with type 2 diabetes with inadequate glycemic control on oral antihyperglycemic medications from a healthcare payer perspective in the Spanish setting.

\section{What was learned from the study?}

Projections of long-term clinical outcomes indicated that once-weekly semaglutide $0.5 \mathrm{mg}$ and $1 \mathrm{mg}$ were associated with improvements in discounted life expectancy of 0.02 and 0.11 years, respectively, and discounted qualityadjusted life expectancy of 0.03 and 0.11 quality-adjusted life years (QALYs), respectively, versus dulaglutide $1.5 \mathrm{mg}$. Compared with sitagliptin, once-weekly semaglutide $0.5 \mathrm{mg}$ and $1 \mathrm{mg}$ were associated with improvements in discounted life expectancy of 0.17 and 0.24 years, respectively, and discounted quality-adjusted life expectancy of 0.16 and 0.23 QALYs.

Avoided diabetes-related complications resulted in once-weekly semaglutide $0.5 \mathrm{mg}$ and $1 \mathrm{mg}$ being cost-saving versus dulaglutide $1.5 \mathrm{mg}$ and sitagliptin $100 \mathrm{mg}$ from a healthcare payer perspective.

Both doses of once-weekly semaglutide were found to be more effective and less costly versus both comparators and therefore were considered dominant.

\section{INTRODUCTION}

Economic evaluation of new healthcare interventions is becoming increasingly important, as healthcare providers aim to maximize health across the population while operating with constrained financial resources [1]. This is particularly pertinent for interventions to treat type 2 diabetes, where the prevalence of the disease continues to increase [2]. The Di@bet.es Study found that the overall prevalence of known and unknown type 2 diabetes in Spain in 2012 was $13.8 \%$ (95\% confidence interval 12.8 to $14.7 \%$ ), and the average annual cost per patient with diabetes was estimated to be EUR 3110, resulting in an annual healthcare expenditure of approximately EUR 10 billion [3].

Modern interventions for type 2 diabetes aim to reduce the risk of diabetes-related complications by controlling hyperglycemia, body weight, blood pressure and serum lipids [4]. Furthermore, the effect of diabetes medications on cardiovascular risk should be considered early in the diabetes treatment algorithm [4]. Optimizing care not only improves life expectancy and quality-adjusted life expectancy for patients, but reducing the incidence of complications can also result in cost savings for healthcare payers, as complications are a key driver of the total cost of diabetes [5]. The options available to clinicians and patients include incretin-based therapies, such as glucagon-like-peptide-1 (GLP-1) receptor agonists and dipeptidyl peptidase 4 (DPP-4) inhibitors. Once-weekly semaglutide is a novel GLP-1 receptor agonist, suitable for once-weekly, subcutaneous administration, available in $0.5 \mathrm{mg}$ and $1 \mathrm{mg}$ weekly maintenance doses. Onceweekly semaglutide $0.5 \mathrm{mg}$ and $1 \mathrm{mg}$ were compared with the once-weekly GLP-1 receptor agonist dulaglutide $0.75 \mathrm{mg}$ and $1.5 \mathrm{mg}$, respectively, in the SUSTAIN 7 randomized controlled trial, and both doses of once-weekly semaglutide were compared with sitagliptin $100 \mathrm{mg}$ once daily (taken orally) in the SUSTAIN 2 randomized controlled trial [6, 7]. The SUSTAIN 7 trial enrolled 1201 participants, including 63 from Spain, while the SUSTAIN 2 trial enrolled 1231 participants, including 69 
from Spain. SUSTAIN 7 included adults aged $\geq$ 18 years with type 2 diabetes and an $\mathrm{HbA} 1 \mathrm{c}$ of $7.0-10.5 \%$, who were on stable treatment with metformin. In the SUSTAIN 2 trial, study participants were adults aged $\geq 18$ years (or aged $\geq$ 20 years in Japan) with type 2 diabetes and an HbA1c $7.0-10.5 \%$ while on stable treatment with metformin, pioglitazone, rosiglitazone or a combination of either metformin and pioglitazone or metformin and rosiglitazone. The primary end point of both clinical trials was change from baseline in glycated hemoglobin (HbA1c), with once-weekly semaglutide $0.5 \mathrm{mg}$ associated with a significantly greater reduction than dulaglutide $0.75 \mathrm{mg}$, once-weekly semaglutide $1 \mathrm{mg}$ associated with a significantly greater reduction than dulaglutide $1.5 \mathrm{mg}$ and both doses of once-weekly semaglutide associated with significantly greater reductions than sitagliptin. Secondary study end points included change in body mass index (BMI), blood pressure and serum lipids.

Previously published analyses have assessed the short-term cost-effectiveness of once-weekly semaglutide versus dulaglutide and sitagliptin over a 1-year time horizon, and the long-term cost-effectiveness of once-weekly semaglutide versus empagliflozin in the Spanish setting $[8,9]$. In the short-term cost-effectiveness analysis, once-weekly semaglutide $0.5 \mathrm{mg}$ and $1 \mathrm{mg}$ were associated with a lower cost per patient achieving the end point of $\mathrm{a} \geq 1.0 \%$ reduction in $\mathrm{HbA} 1 \mathrm{c}$ with $\geq 5.0 \%$ weight loss versus sitagliptin $100 \mathrm{mg}$, a lower cost per patient achieving target end points of HbA1c $<7.0 \%$, HbA1c $<7.0 \%$ without hypoglycemia and without weight gain and $\geq 1.0 \%$ reduction in $\mathrm{HbA} 1 \mathrm{c}$ with $\geq 5.0 \%$ weight loss versus dulaglutide $1.5 \mathrm{mg}$ [8]. In the long-term cost-effectiveness analysis, once-weekly semaglutide $0.5 \mathrm{mg}$ and $1 \mathrm{mg}$ were associated with improved clinical outcomes at an increased overall cost versus empagliflozin $10 \mathrm{mg}$ and $25 \mathrm{mg}$, with both doses of onceweekly semaglutide found to be cost-effective versus both doses of empagliflozin [9]. However, to make informed healthcare decisions, it is important for the cost-effectiveness of novel interventions to be assessed versus all relevant comparators and over all relevant time frames.
The aim of the present analysis was to assess the long-term cost-effectiveness of once-weekly semaglutide $0.5 \mathrm{mg}$ and $1 \mathrm{mg}$ versus dulaglutide $1.5 \mathrm{mg}$ and versus sitagliptin $100 \mathrm{mg}$ for the treatment of patients with type 2 diabetes with inadequate glycemic control on oral anti-hyperglycemic medications from a healthcare payer perspective in the Spanish setting.

\section{METHODS}

\section{Modeling Approach}

The analysis was conducted in line with the previously published cost-effectiveness analysis comparing once-weekly semaglutide with empagliflozin in the Spanish setting [9]. The cost-effectiveness analysis was performed using the IQVIA CORE Diabetes Model (version 9.0), a non-product specific, computer simulation model of diabetes, validated on initial publication in 2004 and following a series of updates in 2014 [10-12]. The model projects the cumulative incidence and time to onset of complications, life expectancy (expressed in years), quality-adjusted life expectancy [expressed in quality-adjusted life years (QALYs)], direct costs and, where appropriate, incremental cost-effectiveness ratios (ICERs). ICERs combine cost and effectiveness outcomes to express the additional cost per additional unit of effectiveness gained for the intervention versus the comparator. Where an intervention is associated with reduced costs and increased clinical benefits, it is considered dominant versus the comparator, and no calculation of an ICER is required. Outcomes with both maintenance doses of once-weekly semaglutide were compared with dulaglutide $1.5 \mathrm{mg}$ and sitagliptin $100 \mathrm{mg}$ over patient lifetimes, in line with guidance on the assessment of cost-effectiveness of interventions for diabetes, with the analysis capturing mortality due to diabetes-related complications and background mortality [13]. Projected clinical benefits and cost outcomes were discounted at $3.0 \%$ annually, in line with methodologic guidelines on cost-effectiveness analyses for Spain [14]. 
As in the previously published analysis, a simple treatment algorithm was used, where patients received once-weekly semaglutide, dulaglutide $1.5 \mathrm{mg}$ or sitagliptin $100 \mathrm{mg}$ for 3 years, at which point these therapies were discontinued and patients received basal insulin therapy with insulin glargine U100 for the remainder of their lifetimes (i.e., treatment costs were equal in all treatment arms following intensification) [9]. This approach is also in agreement with previously published long-term cost-effectiveness analyses of other GLP-1 receptor agonists in Spain [15-17]. After applying treatment effects based on the clinical trial data, differences in HbA1c and BMI were assumed to persist for the 3 years that patients received once-weekly semaglutide, dulaglutide $1.5 \mathrm{mg}$ or sitagliptin $100 \mathrm{mg}$. On intensification, HbA1c was brought to $7 \%$ in all treatment arms, based on the consensus report released by the American Diabetes Association (ADA) and the European Association for the Study of Diabetes (EASD), and BMI returned to baseline $\left(33.5 \mathrm{~kg} / \mathrm{m}^{2}\right.$ in the analysis based on SUSTAIN 7 and $32.5 \mathrm{~kg} / \mathrm{m}^{2}$ in the analysis based on SUTAIN 2) [4]. These assumptions resulted in a balanced cost-effectiveness analysis, with differences in HbA1c and BMI maintained only while there were differences in treatment costs. Full details of all model inputs and a summary of assumptions applied can be found in the supplementary appendix.

\section{Baseline Cohort Characteristics and Treatment Effects}

Baseline cohort characteristics and treatment effects applied in the comparison of onceweekly semaglutide with dulaglutide were taken from the SUSTAIN 7 trial [6]. The mean [standard deviation (SD)] age, duration of diabetes, HbA1c, systolic blood pressure and BMI at baseline were 55.7 (10.6) years, 7.0 (5.7) years, $8.2 \quad(0.9) \%, \quad 133.0 \quad(14.3) \quad \mathrm{mmHg}$ and $33.5(6.8) \mathrm{kg} / \mathrm{m}^{2}$, respectively. Treatment effects and adverse event rates on initiation of onceweekly semaglutide and dulaglutide $1.5 \mathrm{mg}$ were based on changes from baseline at 40 weeks (Table 1 ).
The SUSTAIN 2 clinical trial was used to parameterize the comparison of once-weekly semaglutide with sitagliptin [7]. The mean (SD) age, duration of diabetes, HbA1c, systolic blood pressure and BMI at baseline were 55.1 (10.0) years, 7.0 (5.1) years, $8.1(0.9) \%$, 132.7 (15.9) $\mathrm{mmHg}$ and $32.5(6.2) \mathrm{kg} / \mathrm{m}^{2}$, respectively. The 56-week change from baseline data were used to inform the treatment effects and adverse event rates on initiation of onceweekly semaglutide and sitagliptin $100 \mathrm{mg}$ (Table 1).

\section{Costs and Utilities}

Costs were accounted in euros (EUR) from a healthcare payer perspective in the Spanish setting. Unit costs of medications and consumables were based on wholesale purchasing prices (WPPs). For each product, the pharmacy selling price (PSP) was obtained by applying the conversion factors according to Royal DecreeLaw 4/2010, with rebates according to Royal Decree-Law 8/2010 applied where applicable. Data were extracted in July 2019, reflecting a pricing revision made in May-June 2019, which affected the price of several diabetes medications. Once-weekly semaglutide $0.5 \mathrm{mg}$ and $1 \mathrm{mg}$ were associated with a cost of EUR 86.28 per 28-day pack, dulaglutide $1.5 \mathrm{mg}$ was associated with a cost of EUR 86.28 per 28-day pack, and sitagliptin $100 \mathrm{mg}$ was associated with a cost of EUR 61.66 per 56-day pack. Medication resource use was based on the SUSTAIN 7 and 2 trials from which the clinical data were taken, including concomitant anti-hyperglycemic medication use. In SUSTAIN 7, metformin was the only concomitant medication received and was being taken by $100 \%$ of trial participants. In SUSTAIN 2, 99\% of participants were receiving metformin, $<1 \%$ were receiving a sulfonylurea, and $5 \%$ were receiving a thiazolidinedione. Following intensification after 3 years, patients were assumed to receive $40 \mathrm{U}$ of insulin glargine U100 (based on the defined daily dose).

Costs of complications and quality of life utilities applied in the year of the event and in subsequent years were consistent with the previously published cost-effectiveness analysis of 
Table 1 Treatment effects SUSTAIN 7

\section{Once-weekly semaglutide \\ $0.5 \mathrm{mg}(n=301)$}

Physiologic parameters (applied in the first year of the analysis)

HbAlc (\%)

$-1.51(0.06)$

Systolic blood pressure ( $\mathrm{mmHg}$ )

$$
-2.44(0.76)
$$

Diastolic blood pressure $(\mathrm{mmHg})$

$-0.57(0.48)$

Total cholesterol $(\mathrm{mg} / \mathrm{dl})$

$-7.00(1.72)$

HDL cholesterol $(\mathrm{mg} / \mathrm{dl})$

LDL cholesterol (mg/dl)

$$
-0.46(0.34)^{*}
$$$$
-3.10(1.49)
$$

Triglycerides $(\mathrm{mg} / \mathrm{dl})$

$$
-14.31(3.08)
$$

BMI $\left(\mathrm{kg} / \mathrm{m}^{2}\right)$

$$
-1.63(0.10)^{*}
$$

Estimated glomerular filtration rate $(\mathrm{ml} / \quad-2.42(0.48)$ $\min / 1.73 \mathrm{~m}^{2}$ )

Adverse event rates (applied in the first 3 years of the analysis)

Non-severe hypoglycemia event rate
(events per 100 patient years)
Severe hypoglycemia event rate (events
per 100 patient years)

Once-weekly semaglutide Dulaglutide

$1 \mathrm{mg}(n=300)$

$1.5 \mathrm{mg}(n=299)$

$-1.78(0.06)^{*} \quad-1.37(0.06)$

$-4.88(0.77)^{*} \quad-2.86(0.75)$

$-2.05(0.49)^{*} \quad-0.03(0.47)$

$-5.23(1.76) \quad-2.55(1.75)$

$0.65(0.35) \quad 0.76(0.35)$

$-0.21(1.55) \quad 0.73(1.54)$

$-21.80(2.94) \quad-16.48(3.00)$

$-2.33(0.10)^{*} \quad-1.08(0.10)$

\begin{tabular}{|c|c|c|c|}
\hline HbAlc (\%) & $-1.32(0.05)^{*}$ & $-1.61(0.05)^{*}$ & $-0.55(0.05)$ \\
\hline $\begin{array}{l}\text { Systolic blood pressure } \\
(\mathrm{mmHg})\end{array}$ & $-5.07(0.64)^{*}$ & $-5.61(0.63)^{*}$ & $-2.29(0.67)$ \\
\hline $\begin{array}{l}\text { Diastolic blood pressure } \\
(\mathrm{mmHg})\end{array}$ & $-2.01(0.42)$ & $-1.91(0.42)$ & $-1.11(0.44)$ \\
\hline Total cholesterol (mg/dl) & $-6.24(1.63)$ & $-5.82(1.62)$ & $-2.81(1.74)$ \\
\hline HDL cholesterol (mg/dl) & $-0.06(0.38)$ & $1.55(0.39)^{*}$ & $-0.21(0.40)$ \\
\hline LDL cholesterol $(\mathrm{mg} / \mathrm{dl})$ & $-2.89(1.40)$ & $-2.00(1.41)$ & $0.91(1.53)$ \\
\hline Triglycerides $(\mathrm{mg} / \mathrm{dl})$ & $-16.73(3.20)$ & $-26.65(2.97)^{*}$ & $-14.11(3.43)$ \\
\hline $\operatorname{BMI}\left(\mathrm{kg} / \mathrm{m}^{2}\right)$ & $-1.58(0.09)^{*}$ & $-2.26(0.09)^{*}$ & $-0.68(0.09)$ \\
\hline $\begin{array}{l}\text { Estimated glomerular } \\
\text { filtration rate }(\mathrm{ml} / \mathrm{min} / \\
\left.1.73 \mathrm{~m}^{2}\right)\end{array}$ & $-2.48(0.76)$ & $-2.60(0.77)$ & $-1.94(0.74)$ \\
\hline
\end{tabular}

$-2.80(0.49) \quad-3.51(0.47)$

\begin{tabular}{llll}
\hline SUSTAIN 2 & Once-weekly semaglutide & Once-weekly & Sitagliptin \\
& $0.5 \mathrm{mg}(n=409)$ & semaglutide & $100 \mathrm{mg}(n=407)$ \\
& & $1 \mathrm{mg}(n=409)$ &
\end{tabular}

Physiologic parameters (applied in the first year of the analysis)

Adverse event rates (applied in the first 3 years of the analysis) 
Table 1 continued

\begin{tabular}{|c|c|c|c|}
\hline SUSTAIN 2 & $\begin{array}{l}\text { Once-weekly semaglutide } \\
0.5 \mathrm{mg}(n=409)\end{array}$ & $\begin{array}{l}\text { Once-weekly } \\
\text { semaglutide } \\
1 \mathrm{mg}(n=409)\end{array}$ & $\begin{array}{l}\text { Sitagliptin } \\
100 \mathrm{mg}(n=407)\end{array}$ \\
\hline $\begin{array}{l}\text { Non-severe hypoglycemia } \\
\text { event rate (events per } 100 \\
\text { patient years) }\end{array}$ & 1.61 & 0.46 & 0.66 \\
\hline $\begin{array}{l}\text { Severe hypoglycemia event } \\
\text { rate (events per } 100 \text { patient } \\
\text { years) }\end{array}$ & 0.00 & 0.00 & 0.44 \\
\hline
\end{tabular}

Values are means (standard error)

$B M I$ body mass index, HbAlc glycated hemoglobin

${ }^{*}$ Statistically significant difference at $95 \%$ confidence level for once-weekly $0.5 \mathrm{mg}$ and $1 \mathrm{mg}$ versus the comparator treatment (dulaglutide $1.5 \mathrm{mg}$ or sitagliptin). Modeled treatment effects were based on the 40-week data from SUSTAIN 7 and the 56-week data from SUSTAIN 2, reflecting the primary end points of the two trials

once-weekly semaglutide versus empagliflozin [9]. Costs of complications were identified through literature reviews and were inflated to 2018 values [18-38]. Utilities were taken from a published review, with hypoglycemic event disutilities taken from Evans et al. 2013 (published after the literature searches conducted by Beaudet et al.) $[39,40]$.

\section{Sensitivity Analyses}

The projection of outcomes over patient lifetimes based on short-term clinical trial data (1year of follow up or less) is associated with uncertainty, and therefore a series of sensitivity analyses were performed to test the robustness of the analysis. Sensitivity analyses were prepared for the comparisons of once-weekly semaglutide $1 \mathrm{mg}$ with dulaglutide $1.5 \mathrm{mg}$ and sitagliptin $100 \mathrm{mg}$, as it is anticipated that the majority of patients will receive the higher dose of once-weekly semaglutide for longer due to the greater efficacy and equal price compared with the lower dose.

The importance of uncertainty around the inputs from the SUSTAIN 7 and 2 randomized controlled trials was assessed by applying only treatment effects where the differences between the treatment arms reached statistical significance (Table 1). Where differences were not statistically significant, values in the onceweekly semaglutide $1 \mathrm{mg}$ arm were set to the value in the dulaglutide $1.5 \mathrm{mg}$ or sitagliptin arm, as appropriate. The variation of outcomes as the time horizon of the modeling analysis was changed was evaluated by running analyses over 10, 20 and 35 years. It should be noted that shorter time horizons do not capture all complications and costs, as a time horizon of 50 years was required for all modeled patients to have died. The impact of discounting on the conclusions of the analysis was assessed by performing analyses with discount rates of $0 \%$ and $5 \%$, as per methodologic guidelines on cost-effectiveness analyses for Spain [14].

In the base case analysis, the BMI difference between the treatment arms was abolished when basal insulin was initiated after 3 years of treatment by returning BMI to baseline in both arms, and a sensitivity analysis was performed with the BMI difference between the treatment arms maintained for the duration of patient lifetimes. Similarly, variation of the approach to long-term $\mathrm{HbA1c}$ progression was assessed, with an analysis performed with the United Kingdom Prospective Diabetes Study (UKPDS) HbA1c progression equation applied in both treatment arms. This resulted in HbA1c increasing in both arms of the analysis, with the HbA1c difference gradually abolished. 
To investigate the impact of applying differing treatment effects, a series of four analyses were prepared with the upper and lower limits of the $95 \%$ confidence intervals of the estimated treatment difference in HbA1c and BMI applied in turn. The effect of treatment switching on long-term cost-effectiveness outcomes was assessed in two sensitivity analyses. In the first, treatment switching to basal insulin was delayed until after 5 years of treatment with once-weekly semaglutide $1 \mathrm{mg}$, dulaglutide $1.5 \mathrm{mg}$ or sitagliptin $100 \mathrm{mg}$. In the second analysis, the UKPDS HbA1c progression equation was applied, and patients switched to basal insulin when HbA1c exceeded 7.5\%. To assess the impact of variation in the costs of complications applied, analyses were prepared with the costs of complications increased and decreased by $10 \%$.

The UKPDS 82 risk equations were incorporated into the IQVIA CORE Diabetes Model as part of an update released in February 2014 and were applied in a sensitivity analysis [41]. This approach was chosen as the model proprietors recommend that the UKPDS 68 risk equations are used in the base case analysis [42].

The importance of the impact of change in body weight on long-term cost-effectiveness outcomes was tested by applying an alternative disutility sourced from a publication by Lee et al. in all treatment arms [43]. This disutility was larger than that applied in the base case analysis and therefore gives greater impact to changes in body weight. An analysis was also prepared with a diminishing non-severe hypoglycemia disutility model applied, where the impact of a non-severe event on quality of life reduces as the frequency of events increases [44]. Furthermore, analyses were prepared with alternative disutilities for both non-severe and severe hypoglycemic events applied, based on the values published by Currie et al. [45].

The predefined function in the IQVIA CORE Diabetes Model was used to perform a probabilistic sensitivity analysis (PSA), with sampling around cohort characteristics, treatment effects, complication costs and utilities, with the simulation run using a second order Monte Carlo approach.

\section{Compliance with Ethics Guidelines}

This article is based on previously conducted studies and does not contain any studies with human participants or animals performed by any of the authors.

\section{RESULTS}

\section{Base Case Analyses}

Projections of clinical outcomes over patient lifetimes indicated that once-weekly semaglutide $0.5 \mathrm{mg}$ and $1 \mathrm{mg}$ were associated with improvements in discounted life expectancy of 0.02 [95\% confidence interval (CI) 0.01-0.04] and 0.11 (95\% CI 0.09-0.12) years, respectively, and discounted quality-adjusted life expectancy of 0.03 (95\% CI 0.02-0.04) and 0.11 (95\% CI 0.10-0.12) QALYs, respectively, versus dulaglutide $1.5 \mathrm{mg}$ based on the SUSTAIN 7 trial (Table 2). Compared with sitagliptin based on the SUSTAIN 2 trial, once-weekly semaglutide $0.5 \mathrm{mg}$ and $1 \mathrm{mg}$ were associated with improvements in discounted life expectancy of 0.17 (95\% CI 0.15-0.19) and 0.24 (95\% CI $0.22-0.26)$ years, respectively, and discounted quality-adjusted life expectancy of 0.16 (95\% CI $0.15-0.18$ ) and 0.23 (95\% CI 0.22-0.24) QALYs, respectively, versus sitagliptin (Table 2). In both comparisons, the improved life expectancy and quality adjusted life expectancy with onceweekly semaglutide $0.5 \mathrm{mg}$ and $1 \mathrm{mg}$ resulted from a reduced cumulative incidence and delayed time to onset of diabetes-related complications compared with dulaglutide $1.5 \mathrm{mg}$ and sitagliptin (Fig. 1). Differences were greater for both doses of once-weekly semaglutide in the comparisons with sitagliptin than in the comparisons with dulaglutide $1.5 \mathrm{mg}$, resulting in greater improvements in life expectancy and quality-adjusted life expectancy.

Both doses of once-weekly semaglutide were associated with a small increase in treatment costs versus dulaglutide $1.5 \mathrm{mg}$ (Table 3), despite being associated with the same annual cost of treatment. This resulted from the increased survival and therefore treatment of patients. However, this was offset by cost 
Table 2 Base case results

\begin{tabular}{|c|c|c|c|c|c|c|}
\hline \multicolumn{2}{|l|}{ SUSTAIN 7} & \multicolumn{2}{|c|}{$\begin{array}{l}\text { Once-weekly semaglutide } \\
0.5 \mathrm{mg}\end{array}$} & \multicolumn{2}{|c|}{$\begin{array}{l}\text { Once-weekly semaglutide } \\
1 \mathrm{mg}\end{array}$} & $\begin{array}{l}\text { Dulaglutide } \\
1.5 \mathrm{mg}\end{array}$ \\
\hline \multicolumn{2}{|l|}{ Discounted life expectancy (years) } & \multicolumn{2}{|l|}{$15.03(0.21)$} & \multicolumn{2}{|l|}{$15.11(0.21)$} & $15.01(0.20)$ \\
\hline \multicolumn{2}{|c|}{$\begin{array}{l}\text { Discounted quality-adjusted life expectancy } \\
\text { (QALYs) }\end{array}$} & \multicolumn{2}{|l|}{$9.93(0.14)$} & \multicolumn{2}{|l|}{$10.00(0.14)$} & $9.89(0.14)$ \\
\hline \multicolumn{2}{|l|}{ Discounted direct costs (EUR) } & \multicolumn{2}{|l|}{$61,139(1669)$} & \multicolumn{2}{|l|}{$60,570(1713)$} & $61,417(1805)$ \\
\hline \multicolumn{2}{|c|}{ ICER based on life expectancy and direct costs } & \multicolumn{2}{|c|}{$\begin{array}{l}\text { Once-weekly semaglutide } \\
0.5 \mathrm{mg} \text { dominant }\end{array}$} & \multicolumn{2}{|c|}{$\begin{array}{l}\text { Once-weekly semaglutide } \\
1 \mathrm{mg} \text { dominant }\end{array}$} & - \\
\hline \multicolumn{2}{|l|}{$\begin{array}{l}\text { ICER based on quality-adjusted life } \\
\text { expectancy and direct costs }\end{array}$} & \multicolumn{2}{|c|}{$\begin{array}{l}\text { Once-weekly semaglutide } \\
0.5 \mathrm{mg} \text { dominant }\end{array}$} & \multicolumn{2}{|c|}{$\begin{array}{l}\text { Once-weekly semaglutide } \\
1 \mathrm{mg} \text { dominant }\end{array}$} & - \\
\hline SUSTAIN 2 & \multicolumn{2}{|c|}{$\begin{array}{l}\text { Once-weekly } \\
\text { semaglutide } 0.5 \mathrm{mg}\end{array}$} & \multicolumn{2}{|c|}{$\begin{array}{l}\text { Once-weekly } \\
\text { semaglutide } 1 \mathrm{mg}\end{array}$} & \multicolumn{2}{|c|}{ Sitagliptin $100 \mathrm{mg}$} \\
\hline $\begin{array}{l}\text { Discounted life expectancy } \\
\text { (years) }\end{array}$ & \multicolumn{2}{|c|}{$15.60(0.21)$} & \multicolumn{2}{|c|}{$15.67(0.21)$} & \multicolumn{2}{|c|}{$15.43(0.20)$} \\
\hline $\begin{array}{l}\text { Discounted quality-adjusted life } \\
\text { expectancy (QALYs) }\end{array}$ & \multicolumn{2}{|c|}{$10.34(0.14)$} & \multicolumn{2}{|c|}{$10.41(0.15)$} & \multicolumn{2}{|c|}{$10.17(0.13)$} \\
\hline Discounted direct costs (EUR) & \multicolumn{2}{|c|}{$68,856(1996)$} & \multicolumn{2}{|c|}{$68,170(1983)$} & \multicolumn{2}{|c|}{$68,862(2056)$} \\
\hline $\begin{array}{l}\text { ICER based on life expectancy } \\
\text { and direct costs }\end{array}$ & \multicolumn{2}{|c|}{$\begin{array}{l}\text { Once-weekly semaglutide } \\
0.5 \mathrm{mg} \text { dominant }\end{array}$} & \multicolumn{2}{|c|}{$\begin{array}{l}\text { Once-weekly semaglutide } \\
1 \mathrm{mg} \text { dominant }\end{array}$} & \multicolumn{2}{|l|}{-} \\
\hline $\begin{array}{l}\text { ICER based on quality-adjusted } \\
\text { life expectancy and direct } \\
\text { costs }\end{array}$ & \multicolumn{2}{|c|}{$\begin{array}{l}\text { Once-weekly semaglutide } \\
0.5 \mathrm{mg} \text { dominant }\end{array}$} & \multicolumn{2}{|c|}{$\begin{array}{l}\text { Once-weekly semaglutide } \\
1 \mathrm{mg} \text { dominant }\end{array}$} & \multicolumn{2}{|l|}{-} \\
\hline
\end{tabular}

Values are means (standard deviation)

EUR euros, ICER incremental cost-effectiveness ratio, $Q A L Y s$ quality-adjusted life years

savings as a result of avoided diabetes-related complications, most notably cardiovascular complications with once-weekly semaglutide $0.5 \mathrm{mg}$ (mean cost savings of EUR 113 per patient) and ulcer, amputation and neuropathy complications with once-weekly semaglutide $1 \mathrm{mg}$ (mean cost savings of EUR 665 per patient). Therefore, once-weekly semaglutide $0.5 \mathrm{mg}$ and $1 \mathrm{mg}$ were associated with overall cost savings versus dulaglutide $1.5 \mathrm{mg}$ of EUR 278 (95\% CI EUR 428 to 128) and EUR 847 (95\% CI EUR 999 to 695), respectively. When once-weekly semaglutide was compared with sitagliptin, both doses of once-weekly semaglutide were associated with increased treatment costs because of the higher acquisition cost versus sitagliptin over the first 3 years of the analysis (Table 3). This was entirely offset by reduced costs of diabetes-related complications, with the largest cost savings due to avoided ulcer, amputation and neuropathy complications of EUR 1827 per patient with once-weekly semaglutide $0.5 \mathrm{mg}$ and EUR 2413 per patient with once-weekly semaglutide $1 \mathrm{mg}$. Onceweekly semaglutide $0.5 \mathrm{mg}$ and $1 \mathrm{mg}$ were associated with mean cost savings of EUR 6 (95\% CI of cost saving of EUR 176 to cost increase of EUR 165) and EUR 692 (95\% CI EUR 869 to 515) over patient lifetimes versus sitagliptin.

Once-weekly semaglutide $0.5 \mathrm{mg}$ and $1 \mathrm{mg}$ were associated with improved life expectancy 
a

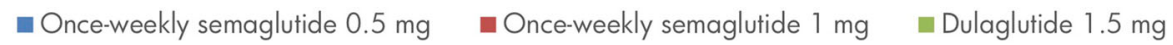

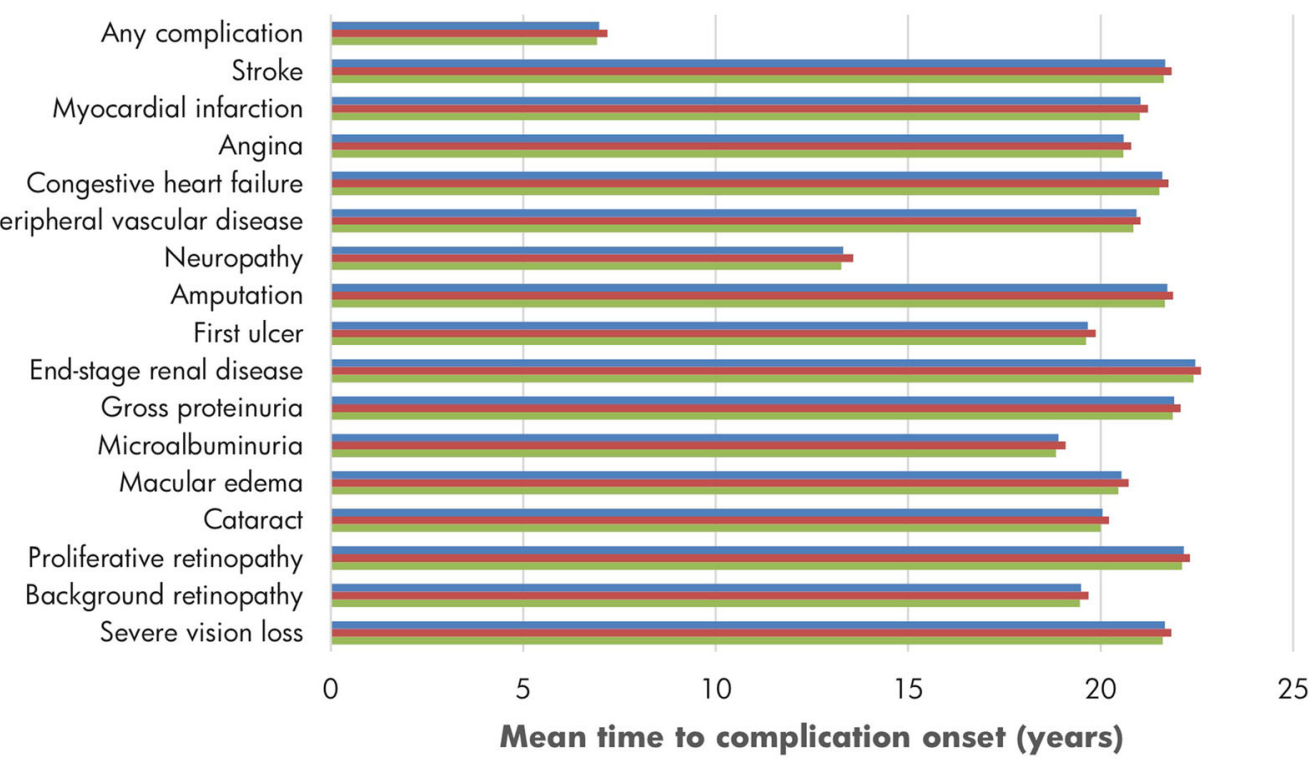

b

@ Once-weekly semaglutide $0.5 \mathrm{mg} \quad$ Once-weekly semaglutide $1 \mathrm{mg} \quad$ a Sitagliptin $100 \mathrm{mg}$

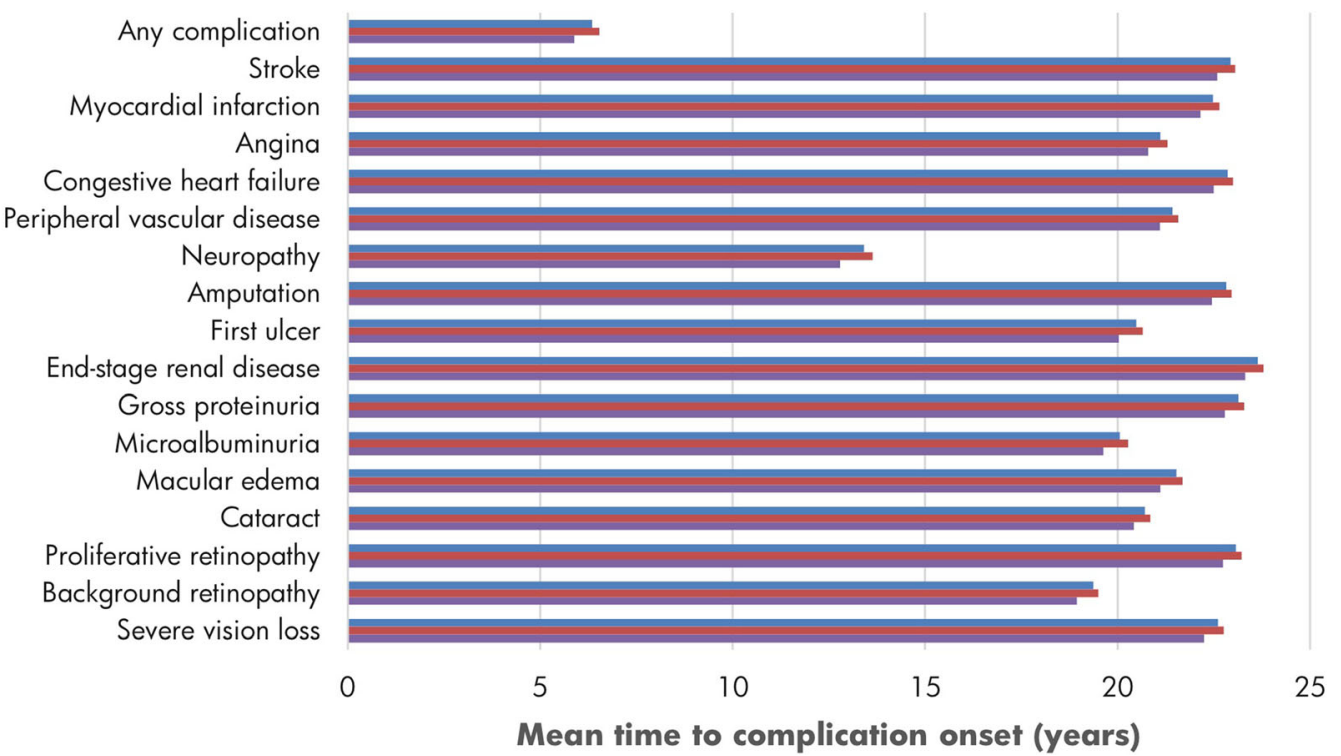

Fig. 1 Mean time to onset of diabetes-related complications. a SUSTAIN 7, b SUSTAIN 2

and quality-adjusted life expectancy, at a reduced cost from a healthcare payer perspective compared with both dulaglutide $1.5 \mathrm{mg}$ and sitagliptin. Therefore, both doses of onceweekly semaglutide were considered dominant versus both comparators.

\section{Sensitivity Analyses}

Across the extensive sensitivity analyses conducted around the base case analyses comparing once-weekly semaglutide $1 \mathrm{mg}$ with dulaglutide $1.5 \mathrm{mg}$ and sitagliptin, once-weekly semaglutide $1 \mathrm{mg}$ remained dominant in all analyses 
Table 3 Mean direct costs over patient lifetimes

\begin{tabular}{|c|c|c|c|c|c|}
\hline SUSTAIN 7 & \multicolumn{2}{|c|}{$\begin{array}{l}\text { Once-weekly semaglutide } \\
0.5 \mathrm{mg} \text { (EUR) }\end{array}$} & \multicolumn{2}{|c|}{$\begin{array}{l}\text { Once-weekly semaglutide } \\
1 \mathrm{mg} \text { (EUR) }\end{array}$} & $\begin{array}{l}\text { Dulaglutide } 1.5 \mathrm{mg} \\
\text { (EUR) }\end{array}$ \\
\hline Treatment & \multicolumn{2}{|c|}{9004} & \multicolumn{2}{|c|}{9040} & 8992 \\
\hline Management & \multicolumn{2}{|c|}{1187} & \multicolumn{2}{|c|}{1193} & 1186 \\
\hline Cardiovascular disease & \multicolumn{2}{|c|}{8865} & \multicolumn{2}{|c|}{8895} & 8978 \\
\hline Renal complications & 717 & & \multicolumn{2}{|c|}{656} & 755 \\
\hline $\begin{array}{l}\text { Ulcer, amputation and } \\
\text { neuropathy }\end{array}$ & \multicolumn{2}{|c|}{38,007} & \multicolumn{2}{|c|}{37,431} & 38,096 \\
\hline Eye complications & \multicolumn{2}{|c|}{1565} & \multicolumn{2}{|c|}{1534} & 1590 \\
\hline Non-severe hypoglycemia & \multicolumn{2}{|c|}{415} & \multicolumn{2}{|c|}{418} & 414 \\
\hline Severe hypoglycemia & \multicolumn{2}{|c|}{1380} & \multicolumn{2}{|c|}{1403} & 1405 \\
\hline Total & \multicolumn{2}{|c|}{61,139} & \multicolumn{2}{|c|}{60,570} & 61,417 \\
\hline \multicolumn{2}{|l|}{ SUSTAIN 2} & \multicolumn{2}{|c|}{$\begin{array}{l}\text { Once-weekly semaglutide } \\
0.5 \mathrm{mg} \text { (EUR) }\end{array}$} & $\begin{array}{l}\text { Once-weekly semaglutide } \\
1 \mathrm{mg} \text { (EUR) }\end{array}$ & $\begin{array}{l}\text { Sitagliptin } \\
100 \mathrm{mg} \text { (EUR) }\end{array}$ \\
\hline Treatment & & 9461 & & 9488 & 7383 \\
\hline Management & & 1228 & & 1234 & 1216 \\
\hline Cardiovascular disease & & 11,446 & & 11,335 & 11,611 \\
\hline Renal complications & & 650 & & 622 & 684 \\
\hline Ulcer, amputation and neu & opathy & 42,255 & & 41,669 & 44,082 \\
\hline Eye complications & & 1947 & & 1936 & 2025 \\
\hline Non-severe hypoglycemia & & 433 & & 435 & 427 \\
\hline Severe hypoglycemia & & 1436 & & 1451 & 1433 \\
\hline Total & & 68,856 & & 68,170 & 68,862 \\
\hline
\end{tabular}

EUR euros

(Table 4). Equivalent patterns were observed in both sets of analyses. Analyses included variation in the treatment effects applied, time horizon of the analysis, discount rates, longterm parameter progression, treatment switching assumptions, costs of complications, utilities applied and risk equations used to predict cardiovascular events. As once-weekly semaglutide $1 \mathrm{mg}$ remained dominant in all tested scenarios, the conclusions of the cost-effectiveness analysis are likely to be robust.

PSA with sampling around cohort characteristics, treatment effects, complication costs and utilities resulted in outcomes similar to those projected in the base case analyses, but with increased measures of variance around the mean outcomes. Once-weekly semaglutide remained dominant versus both dulaglutide $1.5 \mathrm{mg}$ and sitagliptin. The modeling analysis suggests that, at a willingness to pay threshold of EUR 30,000 per QALY gained, there was an $80.4 \%$ probability that once-weekly semaglutide $1 \mathrm{mg}$ was considered cost-effective versus dulaglutide $1.5 \mathrm{mg}$ and an $88.7 \%$ probability that once-weekly semaglutide $1 \mathrm{mg}$ was considered cost-effective versus sitagliptin (Fig. 2). 
Table 4 Results of the sensitivity analyses

\begin{tabular}{|c|c|c|c|c|}
\hline & \multicolumn{2}{|c|}{$\begin{array}{l}\text { Once-weekly semaglutide } 1 \mathrm{mg} \text { versus } \\
\text { dulaglutide } 1.5 \mathrm{mg} \text { (SUSTAIN 7) }\end{array}$} & \multicolumn{2}{|c|}{$\begin{array}{l}\text { Once-weekly semaglutide } 1 \mathrm{mg} \text { versus } \\
\text { sitagliptin } 100 \mathrm{mg} \text { (SUSTAIN 2) }\end{array}$} \\
\hline & $\begin{array}{l}\text { Difference in discounted } \\
\text { quality-adjusted life } \\
\text { expectancy (QALYs) }\end{array}$ & $\begin{array}{l}\text { Difference in } \\
\text { discounted } \\
\text { costs (EUR) }\end{array}$ & $\begin{array}{l}\text { Difference in discounted } \\
\text { quality-adjusted life } \\
\text { expectancy (QALYs) }\end{array}$ & $\begin{array}{l}\text { Difference in } \\
\text { discounted } \\
\text { costs (EUR) }\end{array}$ \\
\hline Base case & +0.11 & -847 & +0.23 & -692 \\
\hline $\begin{array}{l}\text { Statistically significant } \\
\text { differences only }\end{array}$ & +0.11 & -513 & +0.20 & -637 \\
\hline 35-year time horizon & +0.10 & -1114 & +0.20 & -812 \\
\hline 20-year time horizon & +0.07 & -956 & +0.16 & -918 \\
\hline 10-year time horizon & +0.05 & -741 & +0.08 & -56 \\
\hline $0 \%$ discount rates & +0.18 & -1015 & +0.40 & -952 \\
\hline $5 \%$ discount rates & +0.08 & -744 & +0.17 & -475 \\
\hline $\begin{array}{l}\text { BMI difference maintained for } \\
\text { patient lifetimes }\end{array}$ & +0.21 & -739 & +0.36 & -747 \\
\hline $\begin{array}{l}\text { UKPDS HbAlc progression } \\
\text { for duration of the analysis }\end{array}$ & +0.12 & -821 & +0.26 & -442 \\
\hline $\begin{array}{l}\text { Upper limit of } 95 \% \text { CI of } \\
\text { HbAlc estimated treatment } \\
\text { difference }\end{array}$ & +0.11 & -1403 & +0.24 & -1103 \\
\hline $\begin{array}{l}\text { Lower limit of } 95 \% \text { CI of } \\
\text { HbAlc estimated treatment } \\
\text { difference }\end{array}$ & +0.09 & -641 & +0.23 & -362 \\
\hline $\begin{array}{l}\text { Upper limit of } 95 \% \text { CI of BMI } \\
\text { estimated treatment } \\
\text { difference }\end{array}$ & +0.12 & -803 & +0.23 & -659 \\
\hline $\begin{array}{l}\text { Lower limit of } 95 \% \text { CI of BMI } \\
\text { estimated treatment } \\
\text { difference }\end{array}$ & +0.12 & -834 & +0.23 & -714 \\
\hline Treatment switching at 5 years & +0.15 & -1355 & +0.30 & -764 \\
\hline $\begin{array}{l}\text { Treatment switching at } 7.5 \% \\
\text { HbAlc threshold (using } \\
\text { UKPDS HbAlc progression) }\end{array}$ & +0.15 & -443 & +0.35 & -75 \\
\hline Cost of complications $+10 \%$ & +0.11 & -937 & +0.23 & -973 \\
\hline Cost of complications $-10 \%$ & +0.11 & -756 & +0.23 & -410 \\
\hline $\begin{array}{l}\text { UKPDS } 82 \text { risk equations } \\
\text { applied }\end{array}$ & +0.04 & -1364 & +0.11 & -1328 \\
\hline
\end{tabular}


Table 4 continued

\begin{tabular}{|c|c|c|c|c|}
\hline & \multicolumn{2}{|c|}{$\begin{array}{l}\text { Once-weekly semaglutide } 1 \mathrm{mg} \text { versus } \\
\text { dulaglutide } 1.5 \mathrm{mg} \text { (SUSTAIN 7) }\end{array}$} & \multicolumn{2}{|c|}{$\begin{array}{l}\text { Once-weekly semaglutide } 1 \mathrm{mg} \text { versus } \\
\text { sitagliptin } 100 \mathrm{mg} \text { (SUSTAIN 2) }\end{array}$} \\
\hline & $\begin{array}{l}\text { Difference in discounted } \\
\text { quality-adjusted life } \\
\text { expectancy (QALYs) }\end{array}$ & $\begin{array}{l}\text { Difference in } \\
\text { discounted } \\
\text { costs (EUR) }\end{array}$ & $\begin{array}{l}\text { Difference in discounted } \\
\text { quality-adjusted life } \\
\text { expectancy (QALYs) }\end{array}$ & $\begin{array}{l}\text { Difference in } \\
\text { discounted } \\
\text { costs (EUR) }\end{array}$ \\
\hline Lee et al. BMI disutility applied & +0.12 & -847 & +0.24 & -692 \\
\hline $\begin{array}{l}\text { Diminishing hypoglycemia } \\
\text { disutility applied }\end{array}$ & +0.11 & -847 & +0.23 & -692 \\
\hline $\begin{array}{l}\text { Currie et al. hypoglycemia } \\
\text { disutility applied }\end{array}$ & +0.11 & -847 & +0.23 & -692 \\
\hline
\end{tabular}

$B M I$ body mass index, $C I$ confidence interval, EUR euros, HbAIc glycated hemoglobin, QALYs quality-adjusted life years, UKPDS United Kingdom Prospective Diabetes Study

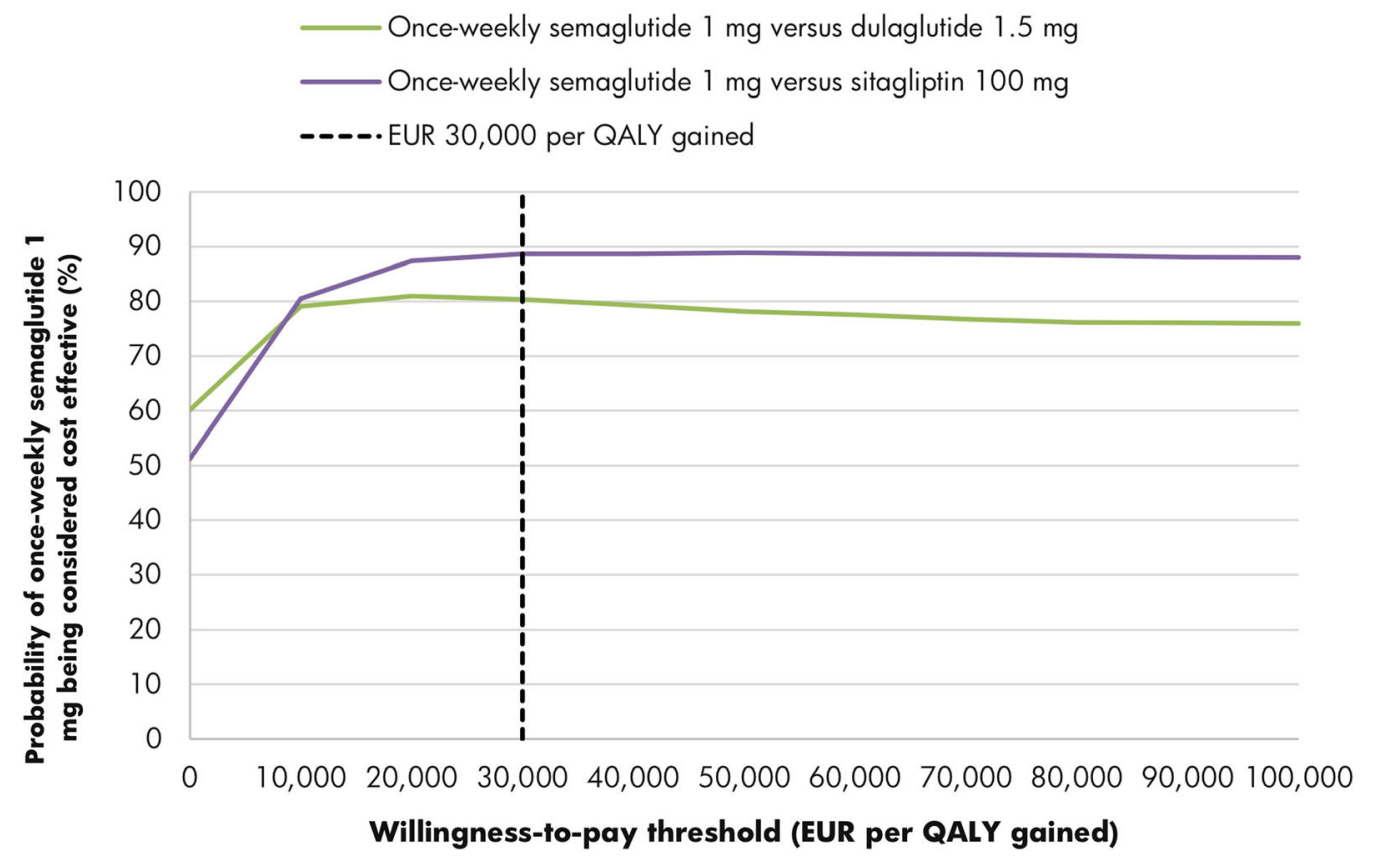

Fig. 2 Cost-effectiveness acceptability curves from the probabilistic sensitivity analysis. EUR euros, $Q A L Y$ quality-adjusted life year

\section{DISCUSSION}

The head-to-head SUSTAIN 2 and 7 clinical trials have shown that once-weekly semaglutide $0.5 \mathrm{mg}$ and $1 \mathrm{mg}$ are associated with improved short-term clinical outcomes compared with sitagliptin $100 \mathrm{mg}$ and dulaglutide $1.5 \mathrm{mg}$ for treatment of patients with type 2 diabetes with inadequate glycemic control on oral anti-hyperglycemic medications. The present longterm cost-effectiveness analysis suggests that these clinical benefits result in reduced cumulative incidence and delayed time to onset of complications, increased life expectancy and increased quality-adjusted life expectancy over the long-term. Projections suggest that 
avoidance of diabetes-related complications with once-weekly semaglutide resulted in cost savings over patient lifetimes versus both sitagliptin and dulaglutide $1.5 \mathrm{mg}$. Therefore, onceweekly semaglutide $0.5 \mathrm{mg}$ and $1 \mathrm{mg}$ were considered dominant versus sitagliptin $100 \mathrm{mg}$ and dulaglutide $1.5 \mathrm{mg}$ for the treatment of patients with type 2 diabetes with inadequate glycemic control on oral anti-hyperglycemic medications and are likely to be a cost-effective use of healthcare resources in the Spanish setting.

The present analysis provides additional data, complementing the previously published cost-effectiveness analyses of once-weekly semaglutide in the Spanish setting. A short-term cost-effectiveness analysis found that onceweekly semaglutide $0.5 \mathrm{mg}$ and $1 \mathrm{mg}$ were associated with a lower cost per patient achieving the end point of $a \geq 1.0 \%$ reduction in $\mathrm{HbA} 1 \mathrm{c}$ with $\geq 5.0 \%$ weight loss versus sitagliptin and a lower cost per patient achieving target end points of HbA1c $<7.0 \%$, HbA1c $<$ $7.0 \%$ without hypoglycemia and without weight gain and $\geq 1.0 \%$ reduction in HbA1c with $\geq 5.0 \%$ weight loss versus dulaglutide $1.5 \mathrm{mg}$ [8]. Furthermore, a long-term cost-effectiveness analysis found that once-weekly semaglutide $0.5 \mathrm{mg}$ and $1 \mathrm{mg}$ were associated with improved clinical outcomes and increased costs versus empagliflozin $10 \mathrm{mg}$ and $25 \mathrm{mg}$, with both doses of once-weekly semaglutide found to be cost-effective versus both doses of empagliflozin [9]. Once-weekly semaglutide $0.5 \mathrm{mg}$ and $1 \mathrm{mg}$ were associated with improvements in discounted quality-adjusted life expectancy of 0.12 and 0.15 QALYs, respectively, versus empagliflozin $10 \mathrm{mg}$ and improvements of 0.11 and 0.14 QALYs, respectively, versus empagliflozin $25 \mathrm{mg}$. Cost increases with once-weekly semaglutide $0.5 \mathrm{mg}$ and $1 \mathrm{mg}$ were EUR 270 and EUR 25, respectively, versus empagliflozin $10 \mathrm{mg}$ and EUR 335 and EUR 89, respectively, versus empagliflozin $25 \mathrm{mg}$. This resulted in once-weekly semaglutide $0.5 \mathrm{mg}$ and $1 \mathrm{mg}$ being associated with ICERs of EUR 2285 and EUR 161 per QALY gained, respectively, versus empagliflozin $10 \mathrm{mg}$ and EUR 3090 and EUR 625 per QALY gained, respectively, versus empagliflozin $25 \mathrm{mg}$. When combined with the results of the present analysis, this body of evidence suggests that onceweekly semaglutide $0.5 \mathrm{mg}$ and $1 \mathrm{mg}$ are likely to be cost-effective therapies for patients with type 2 diabetes with inadequate glycemic control on oral anti-hyperglycemic medications in the Spanish setting. The analysis is also in agreement with cost-effectiveness analyses conducted in other country settings. Onceweekly semaglutide $0.5 \mathrm{mg}$ and $1 \mathrm{mg}$ were both found to be dominant versus dulaglutide $1.5 \mathrm{mg}$ in the UK and Denmark, once-weekly semaglutide $0.5 \mathrm{mg}$ was dominant versus dulaglutide $0.75 \mathrm{mg}$ and once-weekly semaglutide $1 \mathrm{mg}$ was dominant versus dulaglutide $1.5 \mathrm{mg}$ in Canada and The Netherlands, and once-weekly semaglutide $1 \mathrm{mg}$ was dominant versus dulaglutide $1.5 \mathrm{mg}$ in Sweden [46-50]. An additional cost-effectiveness analysis has been conducted in the Slovakian setting, evaluating outcomes in patients with $\mathrm{BMI}>35 \mathrm{~kg} / \mathrm{m}^{2}$ at baseline based on SUSTAIN 7 [51]. In this subgroup of patients, once-weekly semaglutide $0.5 \mathrm{mg}$ and $1 \mathrm{mg}$ were associated with improvements in quality-adjusted life expectancy and cost savings.

At present, the reimbursement of GLP-1 receptor agonists, such as once-weekly semaglutide and dulaglutide, is restricted to people with type 2 diabetes with $\mathrm{BMI} \geq 30 \mathrm{~kg} /$ $\mathrm{m}^{2}$ in Spain. However, no restrictions are applied to the reimbursement of DPP-4 inhibitors, such as sitagliptin. The present analysis was conducted in all people with type 2 diabetes enrolled in the SUSTAIN 7 and 2 clinical trials, with $66.7 \%$ and $62.5 \%$ of participants with BMI $\geq 30 \mathrm{~kg} / \mathrm{m}^{2}$, respectively. The analysis suggested that once-weekly semaglutide would be costsaving compared with sitagliptin in this population, as well as improving clinical outcomes.

The impact of once-weekly semaglutide, dulaglutide and sitagliptin on cardiovascular risk was captured based on traditional risk factors, such as age, duration of diabetes, and HbA1c in the present analysis. However, data from cardiovascular outcomes trials suggest that anti-hyperglycemic medications may have an impact on cardiovascular risk beyond these risk factors. In the SUSTAIN 6 study, once-weekly semaglutide was associated with a statistically 
significant reduction in the incidence of major adverse cardiovascular events (MACE) compared with standard care [52]. Similarly, dulaglutide was associated with a significant reduction in MACE versus standard care in the REWIND study [53]. However, in the TECOS study, sitagliptin was shown to be non-inferior, but not superior, to standard care in terms of frequency of cardiovascular events [54]. It was not possible to include the intervention-specific impact on cardiovascular risk in the present analysis, as risk equations adjusted for this have not yet been published. When adjusted risk equations have been published, reassessment of cost-effectiveness will be an important step to ensure the most efficient use of healthcare resources.

As with all cost-effectiveness analyses, the limitations of the approach must be considered. The present analysis, like the majority of costeffectiveness analyses of new interventions for type 2 diabetes, projected outcomes over patient lifetimes based on short-term clinical trial data. While this approach is recommended in guidelines for economic evaluation of interventions for type 2 diabetes, it is associated with uncertainty [13]. To prepare long-term cost-effectiveness analyses, a number of assumptions are required to extrapolate beyond the shortterm clinical trial data. This includes aspects such as how risk factors such as HbA1c change over time (i.e., beyond the period of the randomized controlled trials), duration of initial treatments, and subsequent treatments and their impacts on risk factors. Throughout the present analysis, assumptions were made in order to prepare a fair and balanced cost-effectiveness analysis that answered the research question around the cost-effectiveness of new interventions for type 2 diabetes. A further limitation was that the impact of adherence was not captured. The cost-effectiveness analysis was based on randomized controlled trials where adherence is likely to be higher than in real-world clinical practice. To date, there is very little evidence of the adherence to the medications included in the present analysis; therefore, an assumption of $100 \%$ adherence was made. As more evidence on adherence becomes available, this should be incorporated into cost-effectiveness analyses. The present analysis included extensive sensitivity analyses to address this uncertainty, with outcomes found to be robust to changes in inputs and assumptions. A published, validated and extensively used model of type 2 diabetes was used to further reduce this uncertainty [10-12].

\section{CONCLUSIONS}

The head-to-head SUSTAIN 2 and 7 clinical trials have shown that once-weekly semaglutide $0.5 \mathrm{mg}$ and $1 \mathrm{mg}$ are associated with improved short-term clinical outcomes compared with sitagliptin $100 \mathrm{mg}$ and dulaglutide $1.5 \mathrm{mg}$ for treatment of patients with type 2 diabetes with inadequate glycemic control on oral anti-hyperglycemic medications. The present cost-effectiveness analysis has suggested that these clinical benefits result in reduced cumulative incidence and delayed time to onset of complications, increased life expectancy and increased quality-adjusted life expectancy over the long-term. Avoidance of diabetes-related complications with once-weekly semaglutide resulted in cost savings over patient lifetimes versus both sitagliptin and dulaglutide $1.5 \mathrm{mg}$. Therefore, once-weekly semaglutide $0.5 \mathrm{mg}$ and $1 \mathrm{mg}$ were considered dominant versus sitagliptin and dulaglutide $1.5 \mathrm{mg}$ for the treatment of patients with type 2 diabetes with inadequate glycemic control on oral anti-hyperglycemic medications and are likely to be a cost-effective use of healthcare resources in the Spanish setting.

\section{ACKNOWLEDGEMENTS}

Funding. The present cost-effectiveness analysis and the Rapid Service and Open Access Fees were funded by Novo Nordisk A/S. All authors had full access to all of the data in this study, take responsibility for the integrity of the work as a whole, and have given approval for the final version to be published. 
Authorship. All named authors meet the International Committee of Medical Journal Editors (ICMJE) criteria for authorship for this article, take responsibility for the integrity of the work as a whole, and have given their approval for this version to be published.

Authorship Contributions. The study was designed by all authors and conducted by Barnaby Hunt and Virginia Martin. The manuscript was drafted by Samuel Malkin and Barnaby Hunt, and revised by Josep Vidal, Virginia Martín and Nino Hallén.

Disclosures. Josep Vidal has the following financial relationships: advisor on scientific boards for Novo Nordisk and lectures for Eli Lilly and Company, Merck Sharp \& Dohme and Novo Nordisk. Samuel Malkin and Barnaby Hunt are employees of Ossian Health Economics and Communications, which received consulting fees from Novo Nordisk A/S to support preparation of the analysis. Virginia Martín is an employee of Novo Nordisk Pharma SA. Nino Hallén is an employee of Novo Nordisk $\mathrm{A} / \mathrm{S}$.

Compliance with Ethics Guidelines. This article is based on previously conducted studies and does not contain any studies with human participants or animals performed by any of the authors.

Data Availability. The datasets generated during and or analyzed during the current study are available from the corresponding author on reasonable request.

Open Access. This article is licensed under a Creative Commons Attribution-NonCommercial 4.0 International License, which permits any non-commercial use, sharing, adaptation, distribution and reproduction in any medium or format, as long as you give appropriate credit to the original author(s) and the source, provide a link to the Creative Commons licence, and indicate if changes were made. The images or other third party material in this article are included in the article's Creative Commons licence, unless indicated otherwise in a credit line to the material. If material is not included in the article's Creative Commons licence and your intended use is not permitted by statutory regulation or exceeds the permitted use, you will need to obtain permission directly from the copyright holder. To view a copy of this licence, visit http://creativecommons.org/licenses/bync/4.0/.

\section{REFERENCES}

1. Hoomans T, Severens JL. Economic evaluation of implementation strategies in health care. Implement Sci. 2014;9:168.

2. Liebl A, Khunti K, Orozco-Beltran D, Yale JF. Health economic evaluation of type 2 diabetes mellitus: a clinical practice focused review. Clin Med Insights Endocrinol Diabetes. 2015;8:13-9.

3. Soriguer F, Goday A, Bosch-Comas A, Bordiú E, Calle-Pascual A, Carmena R, et al. Prevalence of diabetes mellitus and impaired glucose regulation in Spain: the Di@bet.es Study. Diabetologia. 2012;55(1):88-93.

4. Davies MJ, D'Alessio DA, Fradkin J, Kernan WN, Mathieu C, Mingrone G, Rossing P, Tsapas A, Wexler DJ, Buse JB. Management of hyperglycaemia in type 2 diabetes, 2018. A consensus report by the American Diabetes Association (ADA) and the European Association for the Study of Diabetes (EASD). Diabetologia. 2018;61(12):2461-98.

5. Williams R, Van Gaal L, Lucioni C, CODE-2 Advisory Board. Assessing the impact of complications on the costs of Type II diabetes. Diabetologia. 2002;45(7):S13-7.

6. Pratley RE, Aroda VR, Lingvay I, SUSTAIN 7 investigators, et al. Semaglutide versus dulaglutide once weekly in patients with type 2 diabetes (SUSTAIN 7): a randomised, open-label, phase $3 \mathrm{~b}$ trial. Lancet Diabetes Endocrinol. 2018;6(4):275-86.

7. Ahrén B, Masmiquel L, Kumar H, et al. Efficacy and safety of semaglutide versus once-daily sitagliptin as an add-on to metformin, thiazolidinediones, or both, in patients with type 2 diabetes (SUSTAIN 2): a 56-week, double-blind, phase 3a, randomised trial. Lancet Diabetes Endocrinol. 2017;5(5): 341-54.

8. Vidal J, Malkin SJP, Hunt B, Martín V, Hallén N, Javier Ortega F. The short-term cost-effectiveness of once-weekly semaglutide versus once-daily sitagliptin and once-weekly dulaglutide for the 
treatment of patients with type 2 diabetes: a cost of control analysis in Spain. Diabetes Ther. 2020;11(2):509-21.

9. Gorgojo-Martínez JJ, Malkin SJP, Martín V, Hallén $\mathrm{N}$, Hunt B. Assessing the cost-effectiveness of a once-weekly GLP-1 analogue versus an SGLT-2 inhibitor in the Spanish setting: once-weekly semaglutide versus empagliflozin. J Med Econ. 2020;23(2):193-202.

10. Palmer AJ, Roze S, Valentine WJ, Minshall ME, Foos V, Lurati FM, Lammert M, Spinas GA. The CORE Diabetes Model: projecting long-term clinical outcomes, costs and cost-effectiveness of interventions in diabetes mellitus (types 1 and 2) to support clinical and reimbursement decision-making. Curr Med Res Opin. 2004;20(Suppl 1):S5-26.

11. Palmer AJ, Roze S, Valentine WJ, Minshall ME, Foos V, Lurati FM, Lammert M, Spinas GA. Validation of the CORE Diabetes Model against epidemiological and clinical studies. Curr Med Res Opin. 2004;20(Suppl 1):S27-40.

12. McEwan P, Foos V, Palmer JL, Lamotte M, Lloyd A, Grant D. Validation of the IMS CORE Diabetes Model. Value Health. 2014;17(6):714-24.

13. American Diabetes Association Consensus Panel. Guidelines for computer modeling of diabetes and its complications. Diabetes Care. 2004;27(9): 2262-5.

14. Lopez Bastida J, Oliva J, Antonanzas F, Garcia-Altes A, Gisbert R, Mar J, Puig-Junoy J. A proposed guideline for economic evaluation of health technologies. Gac Sanit. 2010;24(2):154-70.

15. Mezquita Raya P, Pérez A, Ramírez de Arellano A, Briones T, Hunt B, Valentine WJ. Incretin therapy for type 2 diabetes in Spain: a cost-effectiveness analysis of liraglutide versus sitagliptin. Diabetes Therapy. 2013;4(2):417-30.

16. Mezquita-Raya P, Ramírez de Arellano A, Kragh N, Vega-Hernandez G, Pöhlmann J, Valentine WJ, Hunt B. Liraglutide versus lixisenatide: long-term cost-effectiveness of GLP-1 receptor agonist therapy for the treatment of type 2 diabetes in Spain. Diabetes Ther. 2017;8(2):401-15.

17. Pérez A, Mezquita Raya P, Ramírez de Arellano A, Briones T, Hunt B, Valentine WJ. Cost-effectiveness analysis of incretin therapy for type 2 diabetes in spain: $1.8 \mathrm{mg}$ liraglutide versus sitagliptin. Diabetes Ther. 2015;6(1):61-74.

18. European Central Bank. Statistical Data Warehouse-Inflation rate (HICP). http://sdw.ecb. europa.eu (last accessed March 21, 2018).
19. Ministerio de Sanidad, Servicios Sociales e Igualdad. Portal estadístico, 2015. ICD-9-CM: 410-Infarto agudo miocardio. http://www.pestadistico.inteligen ciadegestion.msssi.es (last accessed March 21, 2018).

20. Nielsen AT, Pitcher A, Lovato E, Schubert A, Hemels M, Neslusan C, González B. The cost-effectiveness evaluation of canagliflozin versus dapagliflozin in patients with type 2 diabetes mellitus inadequately controlled on metformin monotherapy in Spain. Poster presented at the 20th Annual Meetiong of the International Society for Pharmacoeconomics and Outcomes Research (ISPOR); May 16-20, 2015; Philadelphia. https://www.ispor.org/research_pdfs/ 49/pdffiles/PDB50.pdf (last accessed March 21, 2018).

21. Ministerio de Sanidad, Servicios Sociales e Igualdad. Portal estadístico, 2015. ICD-9-CM: 411.1-Síndrome coronario intermedio; 413-Angina de pecho. http://www.pestadistico.inteligenciadeges tion.msssi.es (last accessed March 21, 2018).

22. Ministerio de Sanidad, Servicios Sociales e Igualdad. Portal estadístico, 2015. ICD-9-CM: 428.0-Insuficiencia cardiaca congestiva. http://www.pesta distico.inteligenciadegestion.msssi.es (last accessed March 21, 2018).

23. Ministerio de Sanidad, Servicios Sociales e Igualdad. Portal estadístico, 2015. ICD-9-CM: 430-hemorragia subaracnoidea; 431-hemorragia intracerebral; 432-Otra hemorragia intracraneal y la no especificada; 433-Oclusión y estenosis de las arterias precerebrales; 434-Oclusión de las arterias cerebrales; 435-Isquemia cerebral transitoria; 436Enfermedad cerebrovascular aguda mal definida; 437-Otra enfermedad cerebrovascular y enfermedad cerebrovascular mal definida; 438-Efectos tardíos de enfermedad cerebrovascular. http:// www.pestadistico.inteligenciadegestion.msssi.es (last accessed March 21, 2018).

24. Ministerio de Sanidad, Servicios Sociales e Igualdad. Portal estadístico, 2015. ICD-9-CM: 443.9-Enfermedad vascular periférica no especificada. http:// www.pestadistico.inteligenciadegestion.msssi.es (last accessed March 21, 2018).

25. Hemodialysis. Tarifas para facturación de servicios sanitarios y docentes de Osakidetza para el año 2017. Osakidetza-Servicio Vasco de Salud. https:// www.osakidetza.euskadi.eus/contenidos/informaci on/libro_tarifas/es_libro/adjuntos/Libro_de_Tarifas _2017.pdf (last accessed March 21, 2018).

26. Peritoneal dialysis. Tarifas para facturación de servicios sanitarios y docentes de Osakidetza para el año 2017. Osakidetza-Servicio Vasco de Salud. https://www.osakidetza.euskadi.eus/contenidos/ informacion/libro_tarifas/es_libro/adjuntos/Libro_ de_Tarifas_2017.pdf (last accessed March 21, 2018). 
27. Ministerio de Sanidad, Servicios Sociales e Igualdad. Portal estadístico, 2015. GRD-AP: 302-Transplante renal. http://www.pestadistico.inteligenciadeges tion.msssi.es (last accessed March 21, 2018).

28. Chubb B, Tikkanen C. The cost of non-severe hypoglycaemia in Europe. Value Health. 2015;18(7):A611.

29. Jakubczyk M, Lipka I, Pawęska J, Niewada M, Rdzanek E, Zaletel J, Ramírez de Arellano A, Doležal T, Chekorova Mitreva B, Nagy B, Petrova G, Šarić T, Yfantopoulos J, Czech M. Cost of severe hypoglycaemia in nine European countries. J Med Econ. 2016;19(10):973-82.

30. Laser photocoagulation. Tarifas para facturación de servicios sanitarios y docentes de Osakidetza para el año 2017. Osakidetza-Servicio Vasco de Salud. https://www.osakidetza.euskadi.eus/contenidos/ informacion/libro_tarifas/es_libro/adjuntos/Libro_ de_Tarifas_2017.pdf (last accessed March 21, 2018).

31. Ministerio de Sanidad, Servicios Sociales e Igualdad. Portal estadístico, 2015. ICD-9-CM: 366.41-Catarata diabética. http://www.pestadistico.inteligen ciadegestion.msssi.es (last accessed March 21, 2018).

32. SP appointment. Tarifas para facturación de servicios sanitarios y docentes de Osakidetza para el año 2017. Osakidetza-Servicio Vasco de Salud. https:// www.osakidetza.euskadi.eus/contenidos/informaci on/libro_tarifas/es_libro/adjuntos/Libro_de_Tarifas _2017.pdf (last accessed March 21, 2018).

33. Ministerio de Sanidad, Servicios Sociales e Igualdad. Portal estadístico, 2015. ICD-9-CM: 369-Ceguera y baja visión. http://www.pestadistico.inteligencia degestion.msssi.es (last accessed March 21, 2018).

34. Ministerio de Sanidad, Servicios Sociales e Igualdad. Portal estadístico, 2015. ICD-9-CM: 249.60-Diabetes mellitus secundaria con manifestaciones neurológicas no consignada como incontrolada o no especificada. http://www.pestadistico.inteligen ciadegestion.msssi.es (last accessed March 21, 2018).

35. Ministerio de Sanidad, Servicios Sociales e Igualdad. Portal estadístico, 2015. GRD-AP: 462-Rehabilitación. http://www.pestadistico.inteligenciadeges tion.msssi.es (last accessed March 21, 2018).

36. Ministerio de Sanidad, Servicios Sociales e Igualdad. Portal estadístico, 2015. ICD-9-CM: 785.4-Gangrena. http://www.pestadistico.inteligenciadeges tion.msssi.es (last accessed March 21, 2018).

37. Ministerio de Sanidad, Servicios Sociales e Igualdad. Portal estadístico, 2015. ICD-9-CM: 707-Úlcera crónica de la piel. http://www.pestadistico. inteligenciadegestion.msssi.es (last accessed March 21, 2018).

38. GP appointment. Tarifas para facturación de servicios sanitarios y docentes de Osakidetza para el año 2017. Osakidetza-Servicio Vasco de Salud. https:// www.osakidetza.euskadi.eus/contenidos/informaci on/libro_tarifas/es_libro/adjuntos/Libro_de_Tarifas _2017.pdf (last accessed March 21, 2018).

39. Beaudet A, Clegg J, Thuresson PO, Lloyd A, McEwan P. Review of utility values for economic modeling in type 2 diabetes. Value Health. 2014;17(4): $462-70$.

40. Evans M, Khunti K, Mamdani M, Galbo-Jorgensen $\mathrm{CB}$, Gundgaard J, Bogelund M, Harris S. Health-related quality of life associated with daytime and nocturnal hypoglycaemic events: a time trade-off survey in five countries. Health Qual Life Outcomes. 2013;11(1):90.

41. Hayes AJ, Leal J, Gray AM, Holman RR, Clarke PM. UKPDS outcomes model 2: a new version of a model to simulate lifetime health outcomes of patients with type 2 diabetes mellitus using data from the 30 year United Kingdom Prospective Diabetes Study: UKPDS 82. Diabetologia. 2013;56(9):1925-33.

42. Clarke PM, Gray AM, Briggs A, Farmer AJ, Fenn P, Stevens RJ, Matthews DR, Stratton IM, Holman RR, UK Prospective Diabetes Study (UKDPS) Group. A model to estimate the lifetime health outcomes of patients with type 2 diabetes: the United Kingdom Prospective Diabetes Study (UKPDS) Outcomes Model (UKPDS no 68). Diabetologia. 2004;47(10): 1747-59.

43. Lee AJ, Morgan CL, Morrissey M, Wittrup-Jensen KU, Kennedy-Martin T, Currie CJ. Evaluation of the association between the EQ-5D (health-related utility) and body mass index (obesity) in hospitaltreated people with Type 1 diabetes, Type 2 diabetes and with no diagnosed diabetes. Diabet Med. 2005;22(11):1482-6.

44. Lauridsen JT, Lønborg J, Gundgaard J, Jensen HH. Diminishing marginal disutility of hypoglycaemic events: results from a time trade-off survey in five countries. Qual Life Res. 2014;23(9):2645-50.

45. Currie CJ, Morgan CL, Poole CD, Sharplin P, Lammert M, McEwan P. Multivariate models of healthrelated utility and the fear of hypoglycaemia in people with diabetes. Curr Med Res Opin. 2006;22(8):1523-34.

46. Viljoen A, Hoxer CS, Johansen P, Malkin S, Hunt B, Bain SC. Evaluation of the long-term cost-effectiveness of once-weekly semaglutide versus dulaglutide for treatment of type 2 diabetes mellitus 
in the UK. Diabetes Obes Metab. 2019;21(3): 611-21.

47. Gæde P, Johansen P, Tikkanen CK, Pollock RF, Hunt B, Malkin SJP. Management of patients with type 2 diabetes with once-weekly semaglutide versus dulaglutide, exenatider, liraglutide and lixisenatide: a cost-effectiveness analysis in the Danish setting. Diabetes Ther. 2019;10(4):1297-317.

48. Johansen P, Håkan-Bloch J, Liu AR, Bech PG, Persson S, Leiter LA. Cost effectiveness of once-weekly semaglutide versus once-weekly dulaglutide in the treatment of type 2 diabetes in Canada. Pharmacoecon Open. 2019;3(4):537-50.

49. Hunt B, Malkin SJP, Moes RGJ, Huisman EL, Vandebrouck T, Wolffenbuttel BHR. Once-weekly semaglutide for patients with type 2 diabetes: a cost-effectiveness analysis in the Netherlands. BMJ Open Diabetes Res Care. 2019;7(1):e000705.

50. Ericsson $\AA$, Fridhammar A. Cost-effectiveness of once-weekly semaglutide versus dulaglutide and lixisenatide in patients with type 2 diabetes with inadequate glycemic control in Sweden. J Med Econ. 2019;22(10):997-1005.

51. Malkin SJP, Russel-Szymczyk M, Psota M, Hlavinkova $\mathrm{L}$, Hunt $\mathrm{B}$. The management of type 2 diabetes with once-weekly semaglutide versus dulaglutide: a long-term cost-effectiveness analysis in Slovakia. Adv Ther. 2019;36:2034-51.
52. Marso SP, Bain SC, Consoli A, Eliaschewitz FG, Jódar E, Leiter LA, Lingvay I, Rosenstock J, Seufert J, Warren ML, Woo V, Hansen O, Holst AG, Pettersson J, Vilsbøll T, SUSTAIN-6 Investigators. Semaglutide and cardiovascular outcomes in patients with type 2 diabetes. $\mathrm{N}$ Engl J Med. 2016;375(19):1834-44.

53. Gerstein HC, Colhoun HM, Dagenais GR, Diaz R, Lakshmanan M, Pais P, Probstfield J, Riesmeyer JS, Riddle MC, Rydén L, Xavier D, Atisso CM, Dyal L, Hall S, Rao-Melacini P, Wong G, Avezum A, Basile J, Chung N, Conget I, Cushman WC, Franek E, Hancu N, Hanefeld M, Holt S, Jansky P, Keltai M, Lanas F, Leiter LA, Lopez-Jaramillo P, Cardona Munoz EG, Pirags V, Pogosova N, Raubenheimer PJ, Shaw JE, Sheu WH, Temelkova-Kurktschiev T, REWIND Investigators. Dulaglutide and cardiovascular outcomes in type 2 diabetes (REWIND): a double-blind, randomised placebo-controlled trial. Lancet. 2019;394(10193):121-30.

54. Green JB, Bethel MA, Armstrong PW, Buse JB, Engel SS, Garg J, Josse R, Kaufman KD, Koglin J, Korn S, Lachin JM, McGuire DK, Pencina MJ, Standl E, Stein PP, Suryawanshi S, Van de Werf F, Peterson ED, Holman RR, TECOS Study Group. Effect of sitagliptin on cardio- vascular outcomes in type 2 diabetes. N Engl J Med. 2015;373:232-42. 